\title{
Environmental conditions and beekeeping practices associated with Nosema ceranae presence in Argentina
}

\author{
Adriana PACINI ${ }^{1,2}$, Ana MolinerI ${ }^{1,2}$, Karina AntúNeZ $^{3}$, Natalia Bulacio CAGNOLO ${ }^{1,2}$, \\ Julieta Merke ${ }^{1,2}$, Emanuel Orellano ${ }^{1,2}$, Ezequiel BertozzI ${ }^{2}$, Luis ZAGO ${ }^{4}$, \\ Andrea Aignasse ${ }^{5}$, Hernán Pietronave ${ }^{2}$, Graciela RodríGuez 6 , \\ María Alejandra PALACio ${ }^{7}$, Marcelo SignORINI ${ }^{1,2}$, Agostina GiaCobino ${ }^{1,2}$

\footnotetext{
${ }^{1}$ Instituto de Investigación de la Cadena Láctea (INTA-CONICET), Estación Experimental Agropecuaria Rafaela, Ruta $34 \mathrm{Km} 227$, Rafaela, Santa Fe, Argentina

${ }^{2}$ Instituto Nacional de Tecnología Agropecuaria EEA Rafaela, Ruta 34 Km 227, 2300, Rafaela, Santa Fe Province, Argentina

${ }^{3}$ Departamento de Microbiología, Instituto de Investigaciones Biológicas Clemente Estable, Av. Italia 3318, CP 11.600, Montevideo, Uruguay

${ }^{4}$ Instituto Nacional de Tecnología Agropecuaria EEA Resistencia, Av. Wilde 5, 3500, Resistencia, Chaco Province, Argentina

${ }^{5}$ Programa para el Desarrollo Apícola, Ministerio de la Producción de la Provincia de Formosa, Belgrano 878 - 6to. Piso, 3600, Formosa, Formosa Province, Argentina

${ }^{6}$ Instituto Nacional de Tecnología Agropecuaria, EEA Hilario Ascasubi, Ruta 3 Km 794, CP 8142, Hilario Ascasubi, Partido de Villarino Buenos Aires, Argentina Argentina
} \\ ${ }^{7}$ Instituto Nacional de Tecnología Agropecuaria, EEA Balcarce, Ruta $226 \mathrm{Km}$ 73,5, CP 7620, Balcarce, Buenos Aires,
}

Received 6 February 2020 - Revised 19 August 2020 - Accepted 1 December 2020

\begin{abstract}
A longitudinal study was carried out in order to evaluate Nosema spp. spore counts in two key moments of the year (late autumn and spring) in honeybee colonies from five eco-regions of Argentina. Three hundred and sixty colonies were randomly selected and the infestation level of Nosema spp. and Varroa destructor was assessed in autumn and spring of 2015. In addition, a questionnaire concerning all management practices applied in the colonies was answered by the beekeepers. Generalized linear mixed effect models were performed to determine the relationship between risk factors associated with Nosema spp. spore counts in each eco-region. Data were scanned to identify colonies cluster with a higher probability of achieving high values of Nosema spp. abundance for each sampling period. Spatial distribution of colonies with a higher risk of achieving high Nosema spp. abundance seems to be explained by geographical conditions associated to climatic conditions and some management practices implemented in each eco-region.
\end{abstract}

environment / management practices / Nosema ceranae / risk factor / Varroa destructor

\section{INTRODUCTION}

Supplementary Information The online version contains supplementary material available at https://doi.org/10.1007 /s13592-020-00831-9.

Corresponding author: A. Pacini, pacini.adriana@inta.gob.ar

Manuscript editor: Peter Rosenkranz
Apis mellifera colony losses episodes have been registered around the world, especially in Europe and the USA (van Engelsdorp et al., 2009; Higes et al., 2010; Le Conte et al., 2010; Lee et al., 2015; Van Der Zee et al. 2014; Jacques et al., 2017; Meana et al., 2017). More recently, honeybee colony losses 
are being focus of research in South America, with similar results to those achieved in Europe and the USA (Giacobino et al. 2016b; Maggi et al. 2016; Antúnez et al. 2016; Requier et al. 2018; Molineri et al. 2018). Different pathogens (e.g., Varroa destructor, Nosema spp., viruses) and other stressors (starvation and pesticide exposure) have been identified as potential factors responsible for the losses of honeybee colonies (Potts et al., 2010; van Engelsdorp and Meixner 2010; Williams et al., 2010; Pettis et al., 2012; Maggi et al., 2016; Steinhauer et al., 2014; Molineri et al., 2018).

Nosemosis is a disease caused by two species of Microsporidia (Phylum Microspora): Nosema apis and Nosema ceranae (Higes et al., 2013). Both are commonly found in adult honeybees (Apis mellifera), and are obligate parasites of the bee's gut, reducing the lifespan of its host (Higes et al., 2008). However, recent studies also found that Nosema spp. infection occurs in brood stages under laboratory (Benvau and Nieh 2017) and natural conditions (Urbieta-Magro et al., 2019), and potentially in larval queens (Traver and Fell 2012). Regarding the impact on A. mellifera colonies, some studies have found that winter colony losses and reduced honey production were related to Nosemosis disease (mostly attributed to N. ceranae) in Europe (Higes et al. 2008, 2009; Soroker et al. 2011; Chauzat et al. 2016) and in South America (Invernizzi et al., 2011; Bravo et al., 2014). However, in other studies associated to colder climates, no link was found between N. ceranae and colony losses (Gisder et al. 2010; Stevanovic et al. n.d.-a, n.d.-b; Dainat et al. 2012; Francis et al. 2014). In Argentina, there are some studies that explored the impact of Nosema spp. in honeybees and their interaction with environmental conditions (Sarlo 2010; Signorini et al. 2014; Giacobino et al. 2016a; Pacini et al. 2016a). Some authors concluded that Nosemosis due to $N$. ceranae infection produces a high mortality of A. mellifera colonies (Sarlo 2010). Other studies could not find a relationship between the counts of Nosema spp. spores and the strength parameters of the colony or mortality related to high Nosema infections (Giacobino et al. 2016a; Signorini et al. 2014; Molineri et al. 2018).

Nosemosis is a widely documented disease in temperate, tropical, and subtropical climates
(Martín-Hernández et al., 2018; Grupe and Quandt 2020). Different reports proposed a climatic influence on the dynamics of $N$. ceranae and $N$. apis infections (Klee et al., 2007; Fries 2010) and virulence (Gisder et al. 2010). One of the most supported evidence is that in colder temperatures, $N$. ceranae infectivity is lower than $N$. apis given spores lose their ability to germinate (Fries 2010; Gisder et al. 2010). On the other hand, the number of spores was higher in N. ceranae than in N. apis infected cells (up to $96 \mathrm{~h}$ post-infection) incubated at $33{ }^{\circ} \mathrm{C}$ (Gisder et al. 2017). Therefore, N. apis proliferation is favored in colder climate as $N$. ceranae spores are more sensitive to freezing temperatures while warmer climates favored it proliferation. At the same time, beekeeping practices can promote the most virulent forms of pathogens through horizontal transmission (Fries and Camazine 2001). In relation to this point, it has been documented that the replacement of old combs can reduce the damage caused by $N$. apis (Fries 1988). Similarly, re-queening practice was associated to spore counts of Nosema spp. as colonies with old queens developed higher infection intensity than colonies with younger queens (Muñoz et al., 2014).

On the other hand, nutritional problems have also been identified as potential factors associated to honeybee colony losses (Goulson et al. 2015). The quality of food for honeybees has markedly declined in the world in the last years (van Engelsdorp and Meixner 2010). Changes in land use are generating a reduction of flower diversity (Kremen et al., 2007), promoted by technological progress and market prices. These reductions in nutritional resources can have a direct impact on honeybee health and particularly is a possible factor associated with Nosemosis (Alaux et al., 2010; Branchiccela et al., 2019).

Seemingly, interspecies competition linked to environmental variables and beekeeping practices are important elements explaining Nosema spp. infection (Martín-Hernández et al. 2018). Thus, the aim of the present work is to assess the influence of environmental conditions combined with beekeeping management promoting development of Nosema spp. under temperate and subtropical regions in order to provide new information about the epidemiology of the infection. 
A. Pacini et al.

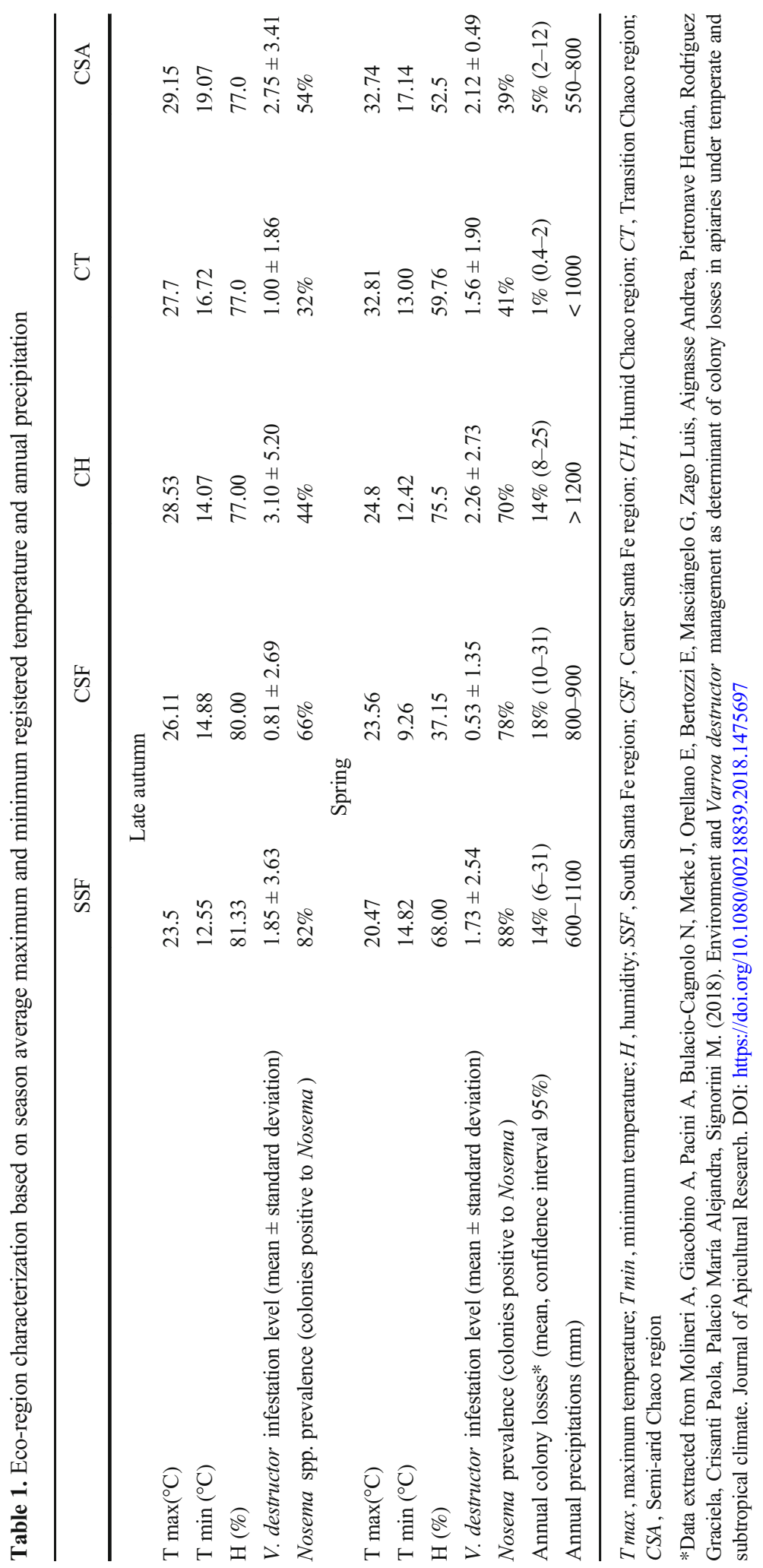




\section{MATERIALS AND METHODS}

\subsection{Study design and sample size}

The study was carried out between autumn and spring of 2015, considering the seasons when Nosema spp. spore counts were higher in similar regions from Argentina (Giacobino et al. 2016a). Colonies located in three provinces of north and central Argentina (Santa Fe, Chaco and Formosa) were sampled. Based on nectar flow period, the beekeeping management schedule, the eco-region categorization (Arzamendia and Giraudo 2004; Burkart et al. 1999; Riveros 2009), and agricultural practices (Giorgi et al., 2008; RIAN 2010) five eco-regions were defined: South Santa Fe, Central Santa Fe, Humid Chaco, Transition Chaco, and Semi-arid Chaco (Table I).

The number of apiaries sampled from each region was determined according to the number of apiaries registered. A total of 360 colonies from 65 apiaries owned by different beekeepers were sampled. The sample size was calculated based on an estimated number of 5300 apiaries in the study area and an expected prevalence of Nosema spp. of $86.1 \%$ (Giacobino et al. 2016a), with a $95 \%$ confidence level and a precision $<10 \%$. Apiaries were randomly chosen following stratified randomization procedures (computerized random numbers) (Moher et al., 2010). Within each apiary, a minimum of five colonies or $10 \%$ of the total colonies (Lee et al., 2010) was randomly selected to evaluate Nosema spp. spore counts and $V$. destructor infestation level.

\subsection{Data collection}

Data collection was assessed three times per colony: early autumn (to account for the initial colony size and health status and to agree a visit schedule with the beekeepers), late autumn (approximately 50 days after first visit), and at the beginning of spring (within 15 days). Due to the long distances, the loss of some participating apiaries could not be avoided so 360 colonies in 65 apiaries, 335 colonies in 59 apiaries, and 289 colonies in 55 apiaries were monitored during early autumn, late autumn, and spring respectively.

\subsubsection{Honeybee colony strength measures}

During each visit to the apiaries, the number of worker bees and the number of cells with sealed brood were estimated visually, according to the Liebefeld method, a suitable method for large amount of high-quality field data (Dainat et al., 2020).

\subsubsection{Nosema spp. spore counts}

During each visit, honeybee foragers were collected at the sealed entrance of the hive and placed in labeled plastic flasks containing $50 \mathrm{~mL}$ of $96 \%$ ethanol. For each sample, 60 bees from the same hive were used. Abdomens were removed with curved tweezers, and spore suspensions were prepared by adding $60 \mathrm{ml}$ of distilled water to crushed abdomens in a mortar with a pestle ( $1 \mathrm{ml}$ of water per bee in the pooled sample according to Fries et al., 2013). A 1-ml aliquot was added to a Neubauer hemocytometer, and Nosema spp. spores/bee was determined using light microscopy 400X (Cantwell 1970; Fries et al., 2013). Results were expressed as mean numbers of Nosema spp. spores/bee. Several studies suggested that proportion of infected bees is a better measurement than the average spore count per bee in a pooled sample (reviewed in Fries et al., 2013). However, the same author stated, "there is a highly significant and positive correlation" between both parameters and that under certain circumstances (e.g., a high number of samples as it is our case) pooled samples can be used.

\subsubsection{V. destructor infestation level}

Adult bees were examined to diagnose the presence of varroa mites during each visit in all selected colonies. In each colony, approximately 250 bees were collected from both sides of three unsealed brood combs in a jar containing 50\% ethanol and soap. The mites were separated from the bees by shacking jars and pouring the jar content into a sieve with a mesh size of 2 $\mathrm{mm}$. The intensity of mite infestation on adult bees was expressed in percentage (Dietemann et al., 2013). 


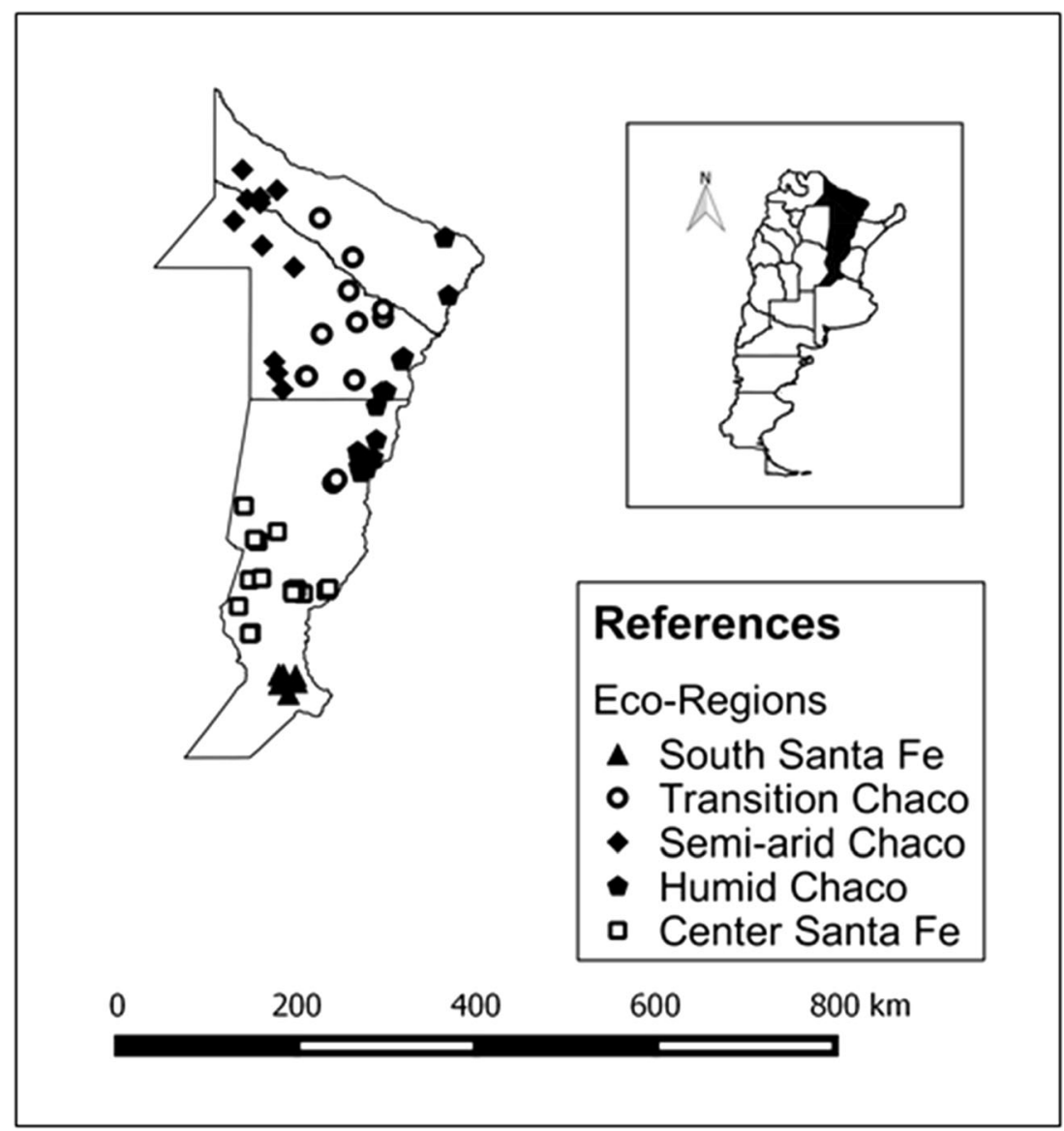

Figure 1. Apiaries location and distribution according to eco-regions from Argentina.

\subsubsection{Questionnaire}

In each visit to the apiaries, management practices performed were obtained from a checklist questionnaire answered by the beekeepers (Supplementary Table S1). The questionnaire gathered information about geographic location, number of colonies, and commonly performed management practices (carbohydrate and protein diets, re-queening, colony migration, apiary location, and the use of plastic bags in winter to protect the brood nest) (Figure 1).

\subsubsection{Determination of Nosema species}

In order to determine the Nosema species present in the apiaries, pools of 50 randomly selected bees per apiary (aprox. 8 bees/colony) from the 59 apiaries sampled in late autumn were analyzed. Genomic DNA was isolated from each pool using the DNeasy Plant Mini Kit (Qiagen, Hilden, Germany) according to the instructions of the manufacturer. Species-specific PCR was carried out as described by Chen et al., (2009). Briefly, DNA extracted from each pool was amplified with two sets of Nosema primers individually. For each run of PCR amplification, a negative control and two positive controls were included, one for each specie (N. apis and N. ceranae).

To confirm those results, a second pool per apiary was analyzed at the Department of Microbiology, IIBCE, Uruguay. DNA was extracted using the PureLink ${ }^{\mathrm{TM}}$ Genomic DNA Mini Kit (Invitrogen), according to the manufacturer's instructions. The presence of $N$. ceranae and/or Nosema apis was analyzed by multiplex PCR, 
Environmental conditions and beekeeping practices associated with Nosema ceranae presence in Argentina 405

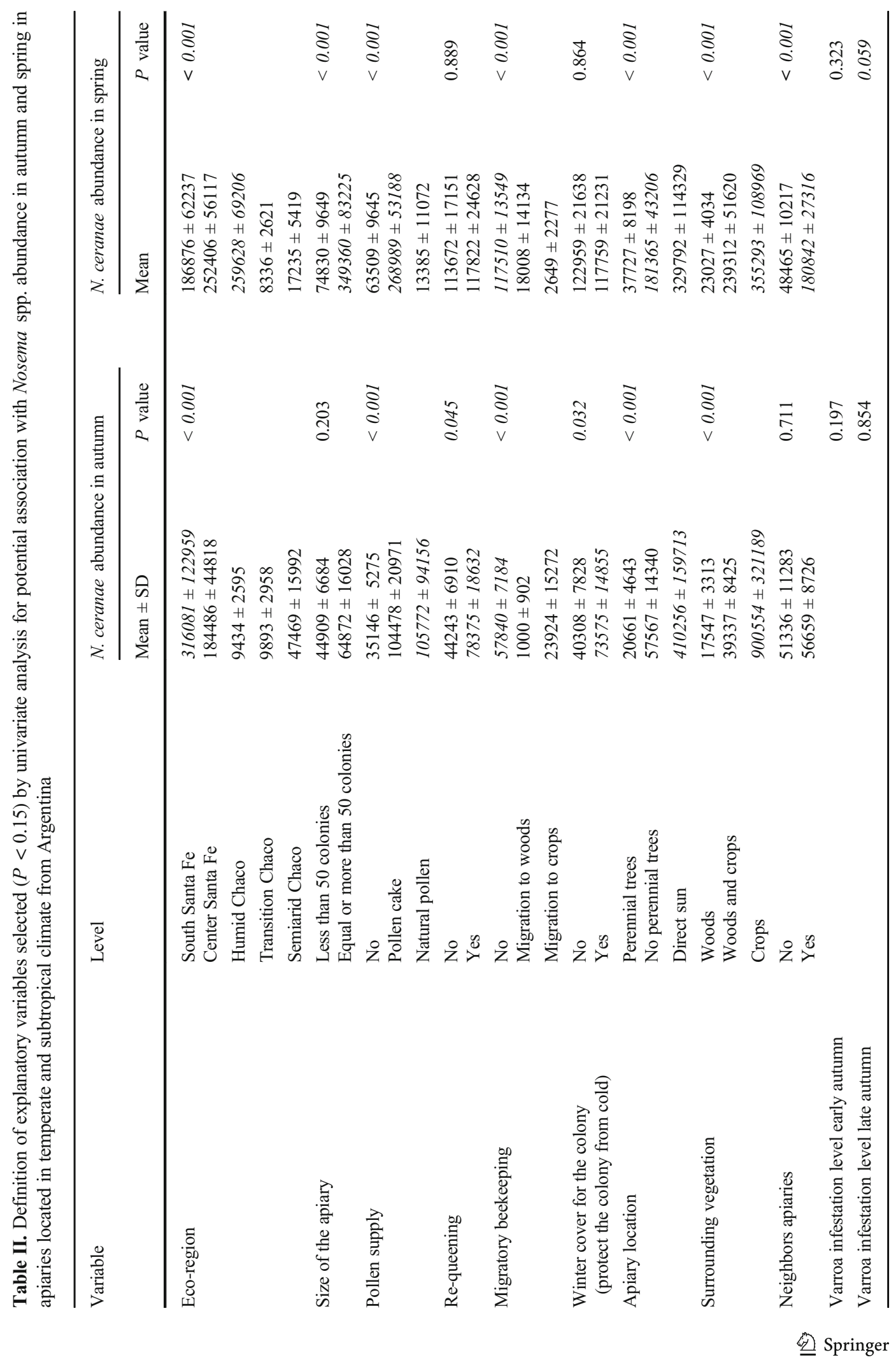


as described by Martin-Hernández et al., (2007). Five microliters of obtained DNA or 1/0 dilution was used for PCR. Positive (N. apis and $N$. ceranae) and negative controls were included in each run.

\subsection{Statistical analysis}

Data was analyzed using a two-step approach. First, a univariate analysis using a generalized linear mixed effect model (GLMM) was conducted for selecting explanatory variables potentially associated with Nosema spp. spore counts in late autumn and spring (before and after winter). For each univariate model (Nosema spp. spore count $\sim$ potential predictor), we assumed a gamma distribution for the outcome variable with a log link function and colony nested in the apiary term as a random effect (as some zeros were measured, we added a constant value of 1000 to all counts). Variables with a $P$ value $\leq 0.15$ were selected for a subsequent multivariable analysis. When two of the explanatory variable explained similar results and were statistically associated (collinearity evaluation), the variable with the lower $P$ value was selected for the multivariate model (Dohoo et al. 1996).

Following, a multivariable analysis was performed using a GLMM to evaluate the effect of the selected explanatory variables on Nosema spp. spore count at each study moment. As mentioned before, we assumed a gamma distribution for the outcome variable with a log link function and colony nested in the apiary term as a random effect. We included the Nosema spp. spore count registered at early autumn as a co-variable in the autumn model and the late autumn spore counts as a co-variable in the spring model. A manually conducted backward elimination strategy was followed by removing one variable with the highest $P$ value at a time, and model selection method based on AIC information was performed (Thrusfield et al. 2018). We compared the population size (number of worker bees) and number of sealed brood between Nosema spp infected and no-infected colonies during early and late autumn and during spring. In addition, the Spearman rank correlation was determined to analyze the relationship between Nosema spp. spore counts and 
the number of adult worker bees and of cells with sealed brood at all three sampling times. All statistical analyzes were carried out using InfoStat software (Universidad Nacional de Córdoba, Argentina).

\subsection{Spatial analysis}

The spatial scan statistic cluster-detection method was used to identify and test the significance of specific clusters for a heterogeneous population distribution (Kulldorff and Nagarwalla 1995). The dataset was scanned to detect areas where Nosema spp. spore counts were significantly lower or higher than expected by chance. A likelihood-ratio test was calculated for each possible "window" and the scanning upper limit was set at $50 \%$ of the population at risk. Nosema spp. spore counts were assumed to follow a normal distribution (uses a likelihood function based on the normal distribution, even when the real distribution of the continuous variable may not be normal), and the most likely cluster along with secondary clusters based on the Gini index criteria were reported (Kulldorff 2014). Finally, risk factors associated with the detected clusters were analyzed using Student's $t$ or Mann Whitney, based on variables distribution. Spatial analysis was performed using SaTScan sof tware version 9.2 (www.satscan.org).

\section{RESULTS}

Nosema spp. spores were detected in 181 out of 360 colonies in early autumn $(50 \%)$, in 181 out of 335 examined colonies in late autumn (54\%), and in 190 out of 289 in spring (66\%). Table I shows the Nosema spp. prevalence and $V$. destructor infestation level per eco-region and sampling moment. Mean Nosema spp. spore counts of the infected colonies were $1.21 \times 10^{6} \pm 2.94 \times 10^{6}$ spores/ bee during autumn and $1.07 \times 10^{6} \pm 2.85 \times$ $10^{6}$ spores/bee during spring. Weak correlations were found between bee population (number of worker bees) and Nosema spp. spore counts during early autumn $(\mathrm{R}=0.17 ; P<0.001)$ and during spring $(\mathrm{R}=-0.30 ; P<0.001)$. In addition, a significant but weak correlation was found between capped brood cells and Nosema spp. spore counts during spring $(\mathrm{R}=-0.16 ; P=0.02)$.

In autumn, South Santa Fe showed the maximum $N$. ceranae spores counts (316081 \pm 122959 spores/ bee) and Humid Chaco the minimum spore counts (9434 \pm 2595 spores/bee). As Table I shows, South Santa Fe has a relative higher percentage of humidity and relative lower temperature than Humid Chaco. In spring, Humid Chaco showed the maximum $N$. ceranae spore counts $(259628 \pm 69206$ spores/bee) and a higher percentage of humidity and

Table 3. Final multivariable logistic regression model (backward selection) for Nosema spp. abundance in 335 honeybee colonies in autumn and spring in apiaries located in temperate and subtropical climate from Argentina

\begin{tabular}{|c|c|c|c|c|c|c|}
\hline \multirow[b]{2}{*}{ Random effect } & \multicolumn{3}{|c|}{ N. ceranae spore counts autumn model } & \multicolumn{3}{|c|}{ N. ceranae spore counts spring model } \\
\hline & Estimate & $95 \% \mathrm{CI}$ & $P$ value & Estimate & $95 \% \mathrm{CI}$ & $P$ value \\
\hline Colony (apiary) & 3.51 & $2.23-3.40$ & $<0.001$ & 2.19 & $1.09-4.39$ & 0.005 \\
\hline Fixed effect & $\mathrm{F}$ & df & $P$ value & $\mathrm{F}$ & $\mathrm{df}$ & $P$ value \\
\hline Eco-region & 11.27 & 4 & $<0.001$ & 13.41 & 4 & $<0.001$ \\
\hline Surrounding vegetation & 13.51 & 2 & $<0.001$ & 9.74 & 2 & $<0.001$ \\
\hline Re-queening & 6.32 & 1 & 0.012 & - & - & - \\
\hline Migratory beekeeping & 11.47 & 1 & $<0.001$ & 17.88 & 2 & $<0.001$ \\
\hline Nosema spp. early autumn & 14.45 & 1 & $<0.001$ & - & - & - \\
\hline Nosema spp. late autumn & - & - & - & 6.21 & 1 & 0.001 \\
\hline Eco-region x Varroa late autumn & - & - & - & 4.80 & 4 & 0.001 \\
\hline
\end{tabular}

Mean in italic showed the maximun value of $\mathrm{N}$. ceranae abundance in each variable associated 
lower temperature than Transition Chaco that showed the minimum $N$. ceranae spore counts $(8336 \pm 2621$ spores/bee) (Table II).

A total of 25 apiaries (46\%) were positives during late autumn for $N$. ceranae when using primers reported by Chen et al., (2009), being this species the only one detected. This was confirmed using the primers and conditions reported by Martin-Hernández et al., (2007). Nosema apis was not detected in any sample although positive controls gave the expected bands.

\subsection{Factors associated with $N$. ceranae spore counts in autumn}

During late autumn, N. ceranae-infected or not infected colonies showed similar bee population and brood cells ( $U$ Mann Whitney 6838.5; $P=$ 0.96; $U$ Mann Whitney $8892 ; P=0.31$, respectively). Previous spore counts registered in the colonies, (e.g., N. ceranae spore counts at early autumn for autumn model and spore counts in late autumn for spring model) were significantly associated and therefore kept as covariates in both models (Table II).

Eight potential explanatory variables out of the initial fourteen were selected to be included in the multivariable GLMM for $N$. ceranae spore counts in autumn (Table II). The potential explanatory variables were eco-region $(P<0.001)$, migratory beekeeping $(P<0.001)$, polen supply $(P<0.001)$, requeening $(P=0.045)$, apiary location $(P<0.001)$, winter cover for the colony $(P=0.032)$, surrounding vegetation $(P<0.001)$, and Nosema spp. spore counts before $V$. destructor treatment $(P<0.001)$.

After the backward analysis, the final model showed five variables significantly associated with autumn $N$. ceranae spore counts (Table III). The colony (apiary) random-effect was significant $(P<$ 0.001). Eco-region was also associated, as Santa Fe's eco-regions had higher spore counts than Chaco`s eco-regions $(P<0.001)$. Similarly, migratory beekeeping $(P<0.001)$ and surrounding vegetation $(P<0.001)$ impact colonies health as fixed apiaries had higher spore counts than migratory apiaries and apiaries surrounded by crops showed the highest spore counts. In the survey, we asked to the respondents to identify "type of vegetation" (woods or/and crops) and if possible to indicate crop diversity. Regarding the latter, beekeepers pointed out that apiaries located solely near crops where surrounded mainly by soybean, maize and/or alfalfa. In contrast, apiaries where re-queening is a frequent practice exhibited lower spore counts than those where re-queening was not performed $(P=0.012)$. In addition, $N$. ceranae spore counts at early autumn were positively correlated with $N$. ceranae spore counts during late autumn $(P<0.001)$.

\subsection{Factors associated with $N$. ceranae spore counts in spring}

During spring, $N$. ceranae-infected colonies showed significantly lower bee population than not infected colonies $(15067 \pm 4420$ and $17362 \pm$ 3918 bees, respectively; $U$ Mann Whitney = 2692.5; $P=0.001)$. Those colonies also showed lower brood cells $(25663 \pm 13324$ and $32232 \pm$ 15982 cells for infected or not infected colonies, respectively; Mann Whitney $=3020 ; P=0.01$ ).

Eleven potential explanatory variables out of the initial fourteen were selected to be included in the multivariable GLMM for N. ceranae spore counts in spring (Table II). The potential explanatory variables were eco-region $(P<0.001)$, apiary size $(P<0.001)$, pollen supply $(P<0.001)$, apiary location $(P<0.001)$, neighboring apiaries $(P<0.001)$, migratory beekeeping $(P<0.001)$, surrounding vegetation $(P<0.001)$, Nosema spp. spore counts at late autumn $(P=0.006)$, $N$. ceranae spore counts in autumn $(P=0.002)$, and varroa infestation in late autumn $(P=0.059)$.

After the backward analysis, the final model included five variables significantly associated with Nosema spp. spore counts in spring (Table III). The colony (apiary) random effect was significant $(P=0.005)$. Eco-region was also associated, as Humid Chaco and Central Santa Fe had higher spore counts than the rest of the ecoregions $(P<0.001)$. Like in autumn, migratory beekeeping $(P<0.001)$ and surrounding vegetation $(P<0.001)$ impact colonies health as fixed apiaries had higher spore counts than migratory apiaries and apiaries surrounded by crops showed the highest spore counts. Furthermore, N. ceranae spore counts in spring were positive correlated to spore counts in late autumn $(P=0.013)$ and significantly associated with varroa level $\mathrm{x}$ eco- 


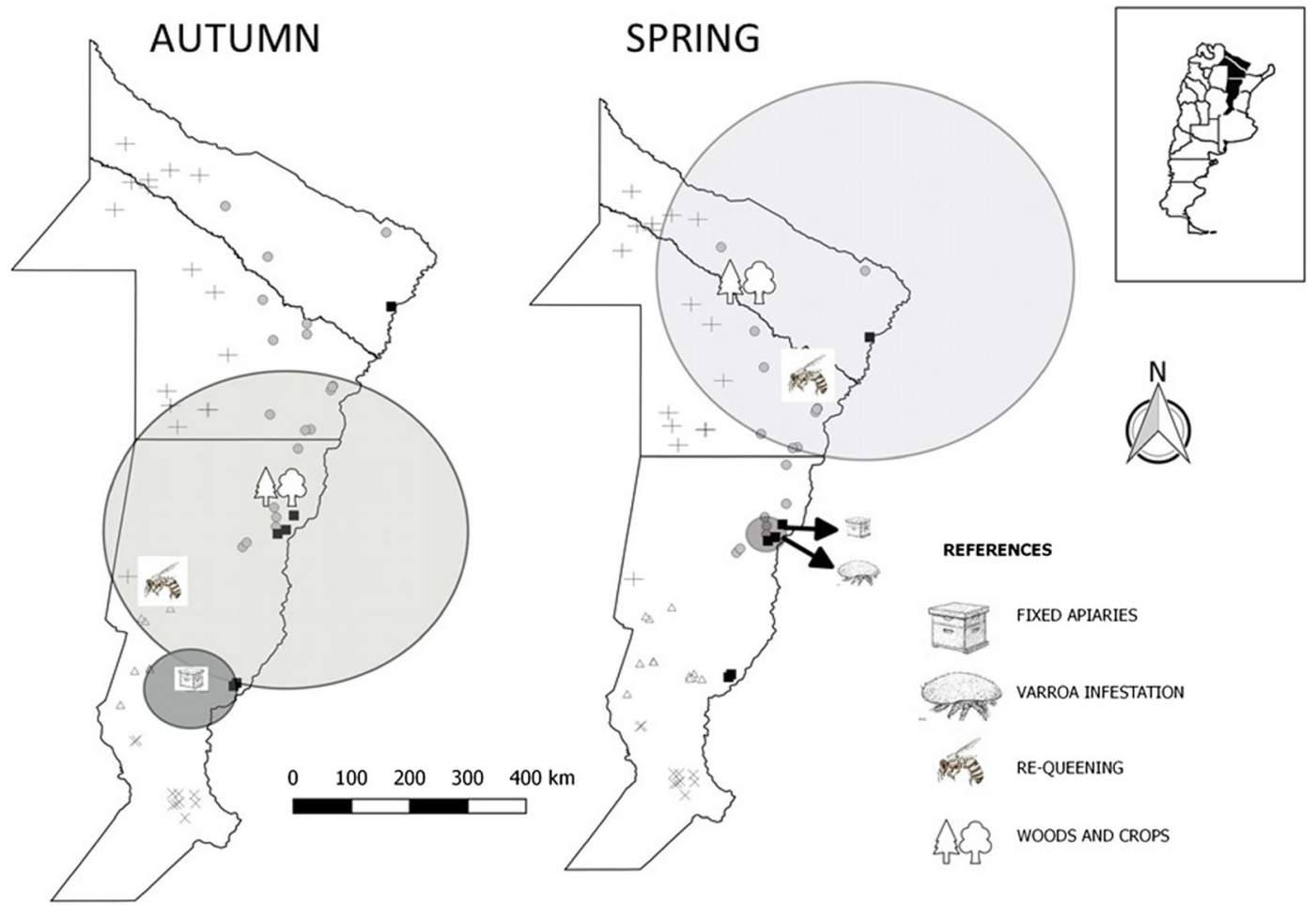

Figure 2. Cluster distribution in autumn and spring in apiaries located under subtropical and temperate climate in Argentina. Dark grey, high Nosema spp. abundance cluster; light grey, low Nosema spp. abundance cluster. X, South Santa Fe; triangle, Central Santa Fe; black square, Warm Chaco; gray circle, Transition Chaco; +, Semi-arid Chaco.

region interaction $(P=0.001)$. Humid Chaco had higher varroa infestation in autumn than the rest of the regions and showed the highest $N$. ceranae spore counts during spring.

\subsection{Spatial analysis}

Three significant clusters were detected in the studied region for $N$. ceranae spore counts in autumn $(P<0.05)$. Two of them were high-count clusters of $1.23 \times 10^{6}$ (47 colonies) and $3.65 \times 10^{5}$ spores/bee (five colonies) respectively. Colonies included in these clusters came from Central Santa $\mathrm{Fe}(90.4 \%)$ and Semi-arid Chaco region $(9.6 \%)$ and were mainly surrounded by wood/crops $(42.5 \%)$, and only crops $(42.5 \%)$. Moreover, all colonies within the high-count clusters were from fixed apiaries. The low-count cluster included 133 colonies and had $8.79 \times 10^{4}$ spores/bee (Figure 2a). In low count-cluster, only $9.5 \%$ of the colonies were surrounded by crops. Most colonies included in this cluster made re-queening (72.5\%).

Two significant clusters were detected in the studied region for $N$. ceranae spore counts in spring: one of high-count and another of lowcount $(P<0.05)$. The high-count cluster has $5.35 \times 10^{6}$ spores/bee (19 colonies), and all colonies included came from Humid Chaco region and was represented by $78.9 \%$ of colonies surrounded by wood/crops. The low-count cluster has $6.20 \times$ $10^{4}$ spores/ bee (91 colonies) (Figure $2 b$ ). Only $17.6 \%$ of the clonies included in this cluster were surrounded by crops.

\section{DISCUSSION}

Despite the fact that this study evaluated Nosema spp. infection in a large number of honeybee colonies distributed in different regions, the total number of apiaries included in each region is low to account for greater geographical and 
biological variations, and therefore, the conclusions are limited.

As expected from previous studies, $N$. ceranae prevalence was similar between early and late autumn and higher during spring (Gisder et al. 2010, 2017). While our study only include three samples (early and late autumn and spring) during 1 year (2015), results support previous findings of Nosema spp. prevalence reaching its peak during late spring and early summer (Gisder et al. 2010; Traver and Fell 2011; Traver et al. 2012). Nosema spp. autumn prevalence reported here was around levels found in Switzerland all over 18 months including all seasons' samples $(46.7 \%)$. However, spring proportion of positive Nosema spp. samples was considerably higher than prevalence found in German colonies during the same period (22-35\%) (Gisder et al. 2010, 2017) but similar to those reported in Virginia state, USA (Traver and Fell 2011) and French colonies (Chauzat et al., 2007). Instead, Nosema crer. intensities quantified here were similar in both seasons. These results are consistent with $N$. ceranae intensity curve described in Chen et al., (2012) for tropical and subtropical conditions. According to the authors, N. ceranae found a peak in winter and infection level is lower than the annual average when the temperature exceeds $23.8^{\circ} \mathrm{C}$. Therefore, spore counts might be similar between spring and autumn because infection level is intensifying from summer to winter and descending from winter to summer. Described mean values $\left(1.21 \times 10^{6}\right.$ and $1.07 \times 10^{6}$ spores/ bee for autumn and spring samples, respectively) are relative low but comparable to previous reports for pooled samples that might include uninfected bees (Retschnig et al., 2017).

Infection with $N$. ceranae was associated with a significant decrease in bee populations during spring but not during previous autumn, suggesting that winter losses are not fully explained by Nosema spp. presence or intensity (Fernández et al., 2012; Stevanovic et al., n.d.-a, n.d.-b; Meixner et al., 2014; Traver et al., 2012). Other studies also failed to associate $N$. ceranae infection intensities and colony strength ratings during spring (Traver and Fell 2011; Traver et al., 2012). Moreover, winter and total colony losses registered in the same study area were not associated to Nosema spp. prevalence (Molineri et al., 2018).

While both Nosema species have been detected in honeybee colonies in Argentina in the past (Pacini et al., 2016a), in this study, N. ceranae appears to be the most prevalent as all the positive colonies were infected exclusively with $N$. ceranae. Medici et al., (2012) reported the predominance of $N$. ceranae in temperate climate from Argentina; however, it does not explain changes in the proportion of samples that resulted positive for $N$. apis earlier during the same year in the same regions (Pacini et al., 2016a). There is evidence suggesting that $N$. ceranae is displacing $N$. apis (reviewed by Martín-Hernández et al., 2012) but it seems to be a slower process than the time period observed here and it should be well documented in order to prove it (Emsen et al. 2015; Gisder et al. 2017). Emsen et al. (2015) found higher levels of infection in $N$. ceranae compared to N. apis parasitized colonies. Additionally, a longitudinal cohort study observed that the autumn prevalence of $N$. apis infections decreased by about $11 \%$ per year (Gisder et al. 2017). Also, regarding $N$. apis seasonality, a small peak in the autumn was reported by Fries (1993) which might coincide with early autumn (March-April) detection reported previously in the same region (Pacini et al., 2016a). Results from late autumn samples in this study were evaluated twice independently in order to check Nosema species in the colonies. Therefore, the difference in $N$. apis presence could be a consequence of $N$. apis seasonal trend combined with relative higher infections of $N$. ceranae.

\subsection{Factors associated to Nosema ceranae spore counts}

In this study, we identified five variables associated with autumn and spring spore counts in colonies from Apis mellifera. Environmental factors like eco-region and surrounding vegetation along with beekeeping practices like re-queening and migratory beekeeping explained (at least partially) the $N$. ceranae spore counts distribution during late autumn season. Similarly, eco-region and surrounding vegetation as well as migratory 
beekeeping described spore counts distribution in the apiaries during spring.

Climate is a main trait in the eco-regions' assemblage and a main factor regarding Microsporidia life cycle (Fries 2010; Meixner et al., 2014). On the one hand, the potential for exposure to spores within the colony increases when adverse weather prevents the cleaning flight by infected bees (Moeller 1972); consequently, temperature may impact on parasite intensity (Retschnig et al., 2017). Colder climates limited the worker ability to defecate outside (Meixner et al., 2014), so it is expected to find higher spore counts in temperate regions compared to more benign environment like subtropical regions. On the other hand, a significant negative correlation of $N$. ceranae intensities with temperature under subtropical climate was reported (Chen et al., 2012). However, a longitudinal study indicated that temperature did not have a clear impact on Nosema spp. infection levels in feral honeybees from the USA (Rangel et al., 2016) suggesting that other factors might be involved. As our results suggested, variations in temperature and humidity alone are not enough to explain Nosema spp. infection level in different regions. Nosema spp. intensity of the infected colonies during autumn and spring is more linked to a group of interconnected drivers, including climate (temperate/subtropical) than to a single factor.

According to the beekeepers answers, soybean, maize, and alfalfa were predominately when apiaries were uniquely surrounded by crops; however, this data rely on each respondent description. Apiaries surrounded mainly by crops showed higher spore counts than colonies located near the woods which may indicate nutritional deficiencies or increased pesticide exposure. For instance, maize produces poor-quality pollen that provides to bees with an inadequate diet for proper development (Di Pasquale et al., 2016). Nutritional deficiencies are strongly linked to Nosema spp. presence (Di Pasquale et al., 2013; Invernizzi et al., 2011). Moreover, Branchiccela et al., (2019) found higher levels of Nosema spp. in colonies under nutritional stress associated to the low quality of Eucalyptus spp pollen. On the other hand, Nosema spp.-infected bees showed elevated spore loads after exposure to some pesticides that are frequently use in extensive agricultural system (Vidau et al., 2011; Pettis et al., 2012 reviewed in Goblirsch 2018). Moreover, Schaaf (2013) conducted a survey of the types of pesticides used in Santa Fe region that revealed the presence of several pesticides linked to higher Nosema spp intensity.

Another factor associated with the occurrence of $N$. ceranae spore counts was the migratory beekeeping. Apiaries owned by beekeepers that move the colonies to the woods had reduced spore counts. There are two aspects to consider regarding this practice. On the one hand, as migratory beekeeping in Argentina is carried out principally to benefit from better and more diverse blooms and increase honey production; these colonies are less likely to undergo nutritional stress eventually associated to Nosema spp. occurrence (Branchiccela et al., 2019). On the other hand, the general health status of these bees tends to be better because beekeepers are encouraged to control diseases before moving the colonies (SENASA 2013). There is a completely different situation when colonies are moved to large monocultures (e.g., almond growing regions in the USA) increasing exposure to pesticides and limiting the floral resources, among other potential negative effects (Simone-Finstrom et al., 2016). Thus, is probable that the advantage of moving the colonies (in this case a lower spore count than colonies from fixed apiaries), it is more associated with where and how it is done than with the practice itself. Some authors point out that is essential the presence of young productive queens in colonies by regular replacement on an annual or biannual basis to maintain colony health and survival, and to increase strength and productivity (Invernizzi et al., 2009, Giacobino et al. $2015 \mathrm{y}$ 2016b). Here, we found that performing requeening is a good predictor for low $N$. ceranae spore counts in autumn season but not for spring counts, probably because most beekeepers performed this practice during late spring during a good nectar flow (Büchler et al., 2014). Some authors, (Simeunovic et al., 2014; Muñoz et al., 2014; Botías et al. 2012b), showed that the replacement with a younger queen decreases the proportion of adults bees infected with Nosema spp. This is associated with the role of a vigorous 
young queen in bee population renewal and the replacement of forager bee lost due to Nosema spp. infection (Moeller 1978; Harris 2008).

Spring model also showed a significant effect of varroa mites and eco-region interaction on spore counts suggesting a strong influence of other pathogens on $N$. ceranae presence (Mariani et al. 2012; Botías et al. 2012a; Pacini et al. 2016b). This might explain at least partially the higher N. ceranae spore counts during spring in the Humid Chaco region (subtropical). While in most of the regions, beekeepers monitored and controlled varroa populations during autumn, colonies from Humid Chaco had the highest varroa mites infestation and variation before winter. Parasitism caused by $V$. destructor is capable of modifying Nosema spp. annual cycle (Mariani et al. 2012; Botías et al. 2012a; Pacini et al. 2016b) thus controlling $V$. destructor infestations in colonies may be vital to mitigate Nosema spp. infection and managing Nosema spp. infections may be beneficial to control the spread of $V$. destructor mites (Little et al., 2016).

\subsection{Spatial analyses}

The location and traits of the cluster groups provide information about the conditions that are favorable for the development and spread of the disease (Pfeiffer et al., 2008). Three high Nosema infestation level clusters were found, two clusters where found in autumn, and one cluster in spring. The clusters analyzed indicated similar associations to those found in relation to risk factors. The high-rate cluster not migrate, almost half of the colonies do not re-queening and were mainly surrounded by crops.

Based on the results from the present study, $N$. ceranae spore counts in autumn and spring are associated with both environmental factors and management practices. Subtropical regions showed reduced spore counts during autumn probably linked to climate and vegetation traits that benefit cleaning behavior, reduced pesticide exposure, and nutritional status. However, migratory beekeeping, re-queening, and $V$. destructor control had a substantial impact on spore counts in both autumn and spring. Consequently, environmental factors alone are not enough to describe
N. ceranae spore counts distribution. This complex interaction between very diverse drivers varying in time and space might explain why a seasonal pattern is difficult to obtain for $N$. ceranae and $N$. apis in different geographic areas.

Scientist and beekeepers have several questions regarding Nosema spp prevalence, intensity, and worldwide distribution; therefore, it is still challenging in the apiculture universe to study these parasites. Further studies should be conducted in order to explain Nosema species seasonality and co-existence under different climates, considering beekeeping practices impact and agricultural landscape interaction.

\section{ACKNOWLEDGMENTS}

We want to thank all the technicians who took the samples for this study. Without them, it would have been impossible to do. Adriana Pacini is post-doctoral fellow; the Drs. Agostina Giacobino, Ana Molineri, and Marcelo L. Signorini are Research Career Members from the Consejo Nacional de Investigaciones Científicas y Técnicas (CONICET, Argentina). We are grateful for the contribution of Karina Antunez in the identification of species and revision of the manuscript.

\section{AUTHOR CONTRIBUTIONS}

PA, MA, SM and GA designed experiments and interpreted the data. BCN, MJ, OE, PMA and RG participated in the design. PA, MA, OE, ZL, $\mathrm{BE}, \mathrm{AA}, \mathrm{PH}$ and GA performed experiments. AK conducted the analysis of Nosema. PA and GA wrote the paper. All authors revised the manuscript.

\section{Funding}

This study has been carried out with the financial support by a grant of ANPCyT, PICT 2016-1568.

Conditions environnementales et pratiques apicoles associées à la présence de Nosema ceranae en Argentine.

Environnement / Pratiques de gestion / Nosema ceranae / Facteur de risque / Varroa destructor. 
Einfluss der Umgebungsbedingungen und der imkerlichen Betriebsweisen auf das Vorkommen von Nosema ceranae in Argentinien.

\section{Umgebung / Betriebsweisen / Nosema ceranae / Risikofaktoren / Varroa destructor.}

\section{REFERENCES}

Alaux, C., Ducloz, F., Crauser, D., Le Conte, Y. (2010). Diet effects on honeybee immune competence. Biol. Lett. $6(4): 562-565$. https://doi.org/10.1098 /rsbl.2009.0986.

Antúnez, K., Invernizzi, C., Mendoza, Y., van Engelsdorp, D., Zunino, P. (2016). Honeybee colony losses in Uruguay during 2013-2014. Apidologie. 48 : 364 370. https://doi.org/10.1007/s13592-016-0482-2.

Arzamendia, V., Giraudo, A. (2004). Usando patrones de biodiversidad para la evaluación y diseño de áreas protegidas: Las serpientes de la provincia de Santa Fe (Argentina) como ejemplo [Using biodiversity patterns for the evaluation and design of protected areas: As an example, snakes in the Santa Fe province (Argentina)]. Rev. Chil. Hist. Nat. 77 (2): 335-348. https://doi. org/10.4067/S0716-078X2004000200011.

Benvau, L.R., Nieh, J.C. (2017). Larval honey bees infected with Nosema ceranae have increased vitellogenin titers as young adults. Sci. Rep. 7 : 1-8. https://doi. org/10.1038/s41598-017-14702-4.

Botias, C., Martín-Hernández, R., Barrios, L., GarridoBailón, E., Nanetti, A., Meana, A., Highes, M. (2012a). Nosema spp. parasitization decreases the effectiveness of acaricide strips (Apivar $®$ ) in treating varroosis of honeybee (Apis mellifera iberiensis) colonies. Environ. Microbiol. Rep. https://doi. org/10.1111/j.1758-2229.2011.00299.x.

Botías, C., Martín-Hernández, R., Días, J., García-Palencia, P., Matabuena, M., Juarranz, A., Barrios, L., Meana, A., Nanetti, A., Higes, M. (2012b). The effect of induced queen replacement on Nosema spp. infection in honeybee (Apis mellifera iberiensis) colonies. Environ. Microbiol. 14(4), 845-859. https://doi. org/10.1111/j.1462-2920.2011.02647.x.

Branchiccela, B., Castelli, L., Corona, M., Díaz-Cetti, S., Invernizzi, C., Martinez de la Escalera, G., Mendoza, Y., Santos, E., Silva, C., Zunino, P., Antunez, K. (2019). Impact of nutrition stress on the honeybee colony health. Sci. Report. 9: 10156. https://doi. org/10.1038/s41598-019-46453-9.

Bravo, J., Carbonell, V., Valdebenito, J.T., Figueroa, C., Valdovinos, C.E., Martín Hernandez, R., et al (2014). Identification of Nosema ceranae in the Valparaíso District, Chile. Arch. Med. Vet. 46: 487-491. https://doi.org/10.4067/S0301.732 X2014000300021.
Büchler, R., Costa, C., Hatjina, F., Andonov, S., Meixner, M., Le Conte, I., Uzunov, A., Berg, S., Bienkowska, M., Bouga, M., Brazic, M., Dyrba, W., Kryger, P., Panasiuk, B., Pechhacker, H., Petrov, P., et al (2014). The influence of genetic origin and its interaction with environmental effects on the survival of Apis mellifera $L$. colonies in Europe. J. Apic. Res. 53 (2): 205-214. https://doi.org/10.3896/IBRA.1.53.2.03.

Burkart, R., Barbaro, N., Sanchez, R., Gomez, D. (1999). Ecoregiones de la Argentina. [Ecoregions from Argentina]. Administración de Parques Nacionales, Buenos Aires. http://www.sib.gov.ar/archivos/Eco-Regiones de_la_Argentina.pdf. Accessed 20 Oct 2017.

Cantwell, G. E. (1970). Standard methods for counting Nosema spores. Am. Bee J. 110, 222-223.

Chauzat, M.P., Higes, M., Martin-Hernandez, R., Meana, A., Cougoule, N., Faucon, J.P. (2007). Presence of Nosema ceranae in French honeybee colonies. J. Apic. Res. $46: 127-128$. https://doi.org/10.1080 /00218839.2007.11101380.

Chauzat, M. P., Jacques, A., EPILOBEE consortium, Laurent, M., Bougeard, S., Hendrikx, P., RibiereChabert, M. (2016). Risk indicators affecting honeybee colony survival in Europe: one year of surveillance. Apidologie. 47:348-378. https://link.springer. com/article/10.1007/s13592-016-0440-z. Accessed 15 Sep 2018.

Chen, Y., Evans, J., Zhou, L., Boncristiani, H., Kimura, K., Xiao, T., Litkowski, A. M., Pettis, J. S. (2009). Asymmetrical coexistence of Nosema ceranae and Nosema apis in honeybees. J. Invertebr. Pathol. 101 : 204-209. https://doi.org/10.1016/j.jip.2009.05.012.

Chen, Y. W., Chung, W. P. , Wang, C. H., Solter, L. F., Huang, W. F. (2012). Nosema ceranae infection intensity highly correlates with temperature. J. Invertebr. Pathol. 111: 264-267. https://doi.org/10.1016/j. jip.2012.08.014.

Dainat, B., Evans, J. D., Chen, Y. P., Gauthier, L., Neumann, P. (2012). Predictive markers of honey bee colony collapse. PLoS One. 7 (2): e32151.

Dainat, B., Dietemann, V., Imdorf, A., Charrière, J. D. (2020). A scientific note on the 'Liebefeld Method' to estimate honeybee colony strength: its history, use, and translation. Apidologie. 51 :422-427. https://link. springer.com/article/10.1007/s13592-019-00728-2. Accessed 10 Jun 2020.

Di Pasquale, G., Salignon, M., Le Conte, Y., Belzunces, L.P., Decourtye, A., et al (2013). Influence of Pollen Nutrition on Honey Bee Health: Do Pollen Quality and Diversity Matter? PLoS One. 8 (8): e72016. https://doi. org/10.1371/journal.pone.0072016.

Di Pasquale, G., Alaux, C., Le Conte, Y., Odoux, J-F., Pioz, M., Vaissière, BE., et al (2016). Variations in the Availability of Pollen Resources Affect Honey Bee Health. PLoS One. 11 (9): e0162818. https://doi. org/10.1371/journal.pone.0162818.

Dietemann, V., Nazzi, F., Martin, S., Anderson, D., Locke, B., et al (2013). Standard methods for varroa research. In V Dietemann, JD Ellis, \& P Neumann (Eds.), The COLOSS BEEBOOK, Volume II: Standard methods 
for Apis mellifera pest and pathogen research. J. Apic. Res. https://doi.org/10.3896/IBRA.1.52.1.09.

Dohoo, I., Ducrot, C., Fourichon, C., Donald, A., Humik, D. (1996). An overview of techniques for dealing with large numbers of independent variables in epidemiologic studies. Prev. Vet. Med. 29, 221-239. https://doi. org/10.1016/S0167-5877(96)01074-4.

Emsen, B., Guzman-Novoa, E., Hamiduzzaman, M., Eccles, L., Lacey, B., Ruiz-Pérez, R., Nasr, M. (2015). Higher prevalence and levels of Nosema ceranae than Nosema apis infections in Canadian honey bee colonies. Parasitol. Res1. 15(1): 175-181. https://doi.org/10.1007/s00436-015-4733-3.

Fernández, J.M., Puerta, F., Cousinou, M., Dios Palomares, R., Campano, F., Redondo, L., (2012). Asymptomatic presence of Nosema spp. in Spanish commercial apiaries. J. Invertebr. Pathol. 111 (2): 106-110. https://doi.org/10.1016/j.jip.2012.06.008.

Francis, R.M., Amiri, E., Meixner, M.D., Kryger, P., Gajda, A., Andonov, S., Uzunov, A., Topolska, G., Charistos, L., Costa, C., Berg, S., Bienkowska, M., Bouga, M., Büchler, R., Dyrba, W., Hatjina, F., Ivanova, E., Kezic, N., Korpela, S., Le Conte, Y., Panasiuk, B., Pechhacker, H., Tsoktouridis, G.,Wilde, J. (2014). Effect of genotype and environment on parasite and pathogen levels in one apiary, a case study. J. Apic. Res. 53 (2): 230-232. https://doi. org/10.3896/IBRA.1.53.2.14.

Fries, I. (1988). Infectivity and multiplication of Nosema apis $\mathrm{Z}$. in the ventriculus of the honeybee. Apidologie. 19 (3): 319-328. https://www.apidologie. org/articles/apido/pdf/1988/03/Apidologie_00448435_1988_19_3_ART0010.pdf. Accessed 20 Feb $2 \overline{0} 18$

Fries, I. (1993). Nosema Apis-A Parasite in the Honey Bee Colony. Bee World. 74 (1): 5-19. https://doi. org/10.1080/0005772X.1993.11099149.

Fries, I. (2010). Nosema ceranae in European honeybees (Apis mellifera ). J. Invertebr. Pathol. 103 (supplement): S73-S79. https://doi.org/10.1016/j.jip.2009.06.017.

Fries, I., Camazine, S. (2001). Implications of horizontal and vertical pathogen transmission for honeybee epidemiology. Apidologie. 32 (3): 199-214. https://doi. org/10.1051/apido:2001122.

Fries, I., Chauzat, M., Chen, Y., Doublet, V., Genersch, E., Gisder, S., et al (2013). Standard methods for Nosema research. In V Dietemann J Ellis, Neumann P (Eds.), The COLOSS BEEBOOK: Volume II: Standard methods for Apis mellifera pest and pathogen research. J. Apic. Res. 52 (1): 1-28. https://doi.org/10.3896 /IBRA.1.52.1.14.

Giacobino, A., Molineri, A., Bulacio-Cagnolo, N., Merke, J., Orellano, E., Bertozzi, E., Masciángelo, G., Pietronave, H., Pacini, A., Salto, C., Signorini, M. (2015). Risk factors associated with failures of Varroa treatments in honeybee colonies without broodless period. Apidologie. 46: 573-582. https://doi. org/10.1007/s13592-015-0347-0.

Giacobino, A., Rivero, R., Molineri, A., Bulacio-Cagnolo, N., Merke, J., Orellano, E., Salto, C., Signorini, M. (2016a). Fumagillin control of Nosema ceranae (Microsporidia: Nosematidae) infection in honeybee (Hymenoptera: Apidae) colonies in Argentina. Veterinaria Italiana http://www.izs.it/vet italiana/2016/52_2/VetIt_120_337_6.pdf. Accessed 12 Nov 2018.

Giacobino, A., Molineri, A., Bulacio-Cagnolo, N., Merke, J., Orellano, E., Bertozzi, E., Masciángelo, G., Pietronave, H., Pacini, A., Salto, C., Signorini, M. (2016b). Key management practices to prevent high infestation levels of Varroa destructor in honeybee colonies at the beginning of the honey yield season. Prev. Vet. Med. 131 : 95-102. https://doi.org/10.1016 /j.prevetmed.2016.07.013.

Giorgi R, Tosolini R, Sapino V, Villar J, León C, Chiavassa, A. (2008). Zonificación Agroeconómica de la provincia de Santa Fe. [Agroeconomic zonification in Santa Fe province] Publicación miscelánea. EEA. Rafaela. $110: 215-224$.

Gisder, S., Hedtke, K., Möckel, N., Frielitz, M., Linde, A., Genersch, E. (2010). Five-year cohort study of Nosema spp. in Germany: does climate shape virulence and assertiveness of Nosema ceranae? Appl. Environ. Microbiol. 76 : 3032-3038. https://aem.asm. org/content/aem/76/9/3032.full.pdf. Accessed 3 Jun 2018 .

Gisder, S., Schüler, V., Horchler, L.L., Growth, D., Genersch, E. (2017). Long-Term Temporal Trends of Nosema spp. Infection Prevalence in Northeast Germany: Continuous Spread of Nosema ceranae, an Emerging Pathogen of Honeybees (Apis mellifera), but No General Replacement of Nosema apis. Front. Cell. Infect. Microbiol. 7 : 301. https://doi.org/10.3389 /fcimb.2017.00301.

Goblirsch, M. (2018). Nosema ceranae disease of the honeybee (Apis mellifera). Apidologie. 49: 131-150. https://doi.org/10.1007/s13592-017-0535-1.

Goulson D., Nicholls E., Botías C., Rotheray E. L., (2015). Bee declines driven by combined stress from parasites, pesticides, and lack of flowers. Science, 347-6229. https://doi.org/10.1126/science. 1255957.

Grupe, A. C., Quandt, A. C. (2020). A growing pandemic: A review of Nosema parasites in globally distributed domesticated and native bees. PLoS Pathog. 16(6): e1008580. https://doi.org/10.1371/journal. ppat. 1008580 .

Harris, J.L. (2008). Effect of requeening on fall populations of honey bees on the northern great plains of North America. J. Apic. Res. 47: 271-280. https://doi. org/10.1080/00218839.2008.11101474.

Higes, M., Martín-Hernández, R., Botías, C., Garrido Bailón, E., González-Porto, A., Barrios, L., del Nozal, M., Bernal, J. L., Jiménez, J. J., García Palencia, P., Meana, A. (2008). How natural infection by Nosema ceranae causes honeybee colony collapse. Environ. Microbiol. 10, 2659-2669. https://doi.org/10.1111 jj.1462-2920.2008.01687.x.

Higes, M., Martin-Hernandez, R., Garcia-Palencia, P., Martín, P., Meana, A. (2009). Horizontal transmission of Nosema ceranae (Microsporidia) from worker 
honeybees to queens (Apis mellifera). Environ. Microbiol. Rep. 1 (6): 495-498. https://doi. org/10.1111/j.1758-2229.2009.00052.x.

Higes, M., Martín-Hernández, R., Martinez-Salvador, A., Garrido-Bailón, E., González-Porto, A., et al (2010). A preliminary study of the epidemiological factors related to honeybee colony loss in Spain. Environ. Microbiol. 2 (2): 243-250. https://doi.org/10.1111 /j.1758-2229.2009.00099.x.

Higes, M., Meana, A., Bartolomé, C., Botías, C., MartínHernández, R (2013). Nosema ceranae (Microsporidia), a controversial 21st century honey bee pathogen. Environ. Microbiol. Rep. 5(1): 17-29. https://doi.org/10.1111/1758-2229.12024.

Invernizzi, C., Abud, C., Tomasco, I., Harriet, J., Ramallo, G., Campá, J., Katz, H., Gardiol, G., Mendoza, Y. (2009). Presence of Nosema ceranae in honeybees (Apis mellifera) in Uruguay. J. Invertebr. Pathol. 101 (2): 150-153. https://doi.org/10.1016/j. jip.2009.03.006.

Invernizzi, C., Santos, E., García, E., Daners, G., Di Landro, R., et al (2011). Sanitary and nutritional characterization of honeybees colonies in Eucalyptus grandis plantations. Archivos de Zootecnia, 60 (232): 1303-1314.

Jacques, A., Laurent, M., EPILOBEE Consortium, RibièreChabert, M., Saussac, M., Bougeard, S., et al. (2017). A pan-European epidemiological study reveals honeybee colony survival depends on beekeeper education and disease control. PLoS One. 12 (3): e0172591. https://doi.org/10.1371/journal.pone.0172591.

Klee, J., Besana A.M., Genersch, E., Gisder, S., Nanetti, A., Tam D.Q., Chinh, T.X., Puerta, F., Ruze J.M., Kryger, P., Message, D., Hatjina, F., Korpela, S., Fries, I., Paxton R.J. (2007). Widespread dispersal of the microsporidian Nosema ceranae, an emergent pathogen of the western honey bee, Apis mellifera. J. Invertebr. Pathol. 96: 1-10. https://doi.org/10.1016/j. jip.2007.02.014.

Kremen, C., Williams, N., Aizen, M., Gemmill-Herren, B., LeBuhn, G., Minckley, R., Packer, L., Potts, S. G., Roulston, T., Dewenter, I. S., Vázquez, D. P., Winfree, R., Adams, L., Crone, E. E., Greenleaf, S. S., Keitt, T. H., Klein, A. M., Regetz, J., Ricketts, T. H. (2007). Pollination and other ecosystem services produced by mobile organisms: a conceptual framework for the effects of land-use change. Ecol. Lett. 10 (4): 299-314. https://doi.org/10.1111/j.1461-0248.2007.01018.x.

Kulldorff, M. (2014). SaTScan User Guide for version 9.3. Retrieved from: http://www.satscan.org.

Kulldorff, M., Nagarwalla, N. (1995). Spatial disease clusters: Detection and inference. Stat. Med. 14(8): 799810. https://doi.org/10.1002/sim.4780140809

Le Conte, Y., Ellis, M., Ritter, W. (2010). Varroa mites and honeybee health. Can Varroa explain part of the colony losses? Apidologie. 41 (3): 353-363. https://doi. org/10.1051/apido/2010017.

Lee, K., Moon, R., Burkness, E., Hutchison, W., Spivak, M. (2010). Practical sampling plans for Varroa destructor (Acari: Varroidae) in Apis mellifera
(Hymenoptera: Apidae) colonies and apiaries. J. Econ. Entomol. 103 (4): 1039-1050. https://doi.org/10.1603 /EC10037.

Lee, K., Steinhauer, N., Travis, D., Meixner, M., Deen, J., van Engelsdorp, D. (2015) Honeybee surveillance: a tool for understanding and improving honeybee health. Curr. Opin. Insect Sci. 10: 37-44. https://doi. org/10.1016/j.cois.2015.04.009.

Little, C., Shutler, D., Williams, G. (2016). Associations among Nosema spp. fungi, Varroa destructor mites, and chemical treatments in honeybees, Apis mellifera. J. Apic. Res. https://doi.org/10.1080 /00218839.2016.1159068.

Maggi, M., Antúnez, K., Invernizzi, C., Aldea, P., Vargas, M., Negri, P., Brasesco, C., De Jong, D., Message, D., Weinstein Texeira, E., Principal, J., Barrios, C., Ruffinengo, S., Rodríguez Da Silva, S., Eguaras, M. (2016). Honeybee health in South America. Apidologie. 47: 835-854. https://doi.org/10.1007 /s13592-016-0445-7.

Mariani, F., Maggi, M., Porrini, M., Fuselli, S., Caraballo, G., Brasesco, C., Barrios, C., Principal, J., Eguaras, M. (2012). Parasitic interactions between Nosema spp. and Varroa destructor in Apis mellifera colonies. Zootec. Trop. 30 (1): 81-90. Available in: http:/www.bioline.org.br/abstract?zt12009. Accessed 3 Jun 2018.

Martin-Hernández, R., Meana, A., Prieto, L., Martinez Salvador, A., Garrido Bailón, E., Higes, M. (2007). Outcome of Colonization of Apis mellifera by Nosema ceranae. Appl. Environ. Microbiol. 73 : 6331-6338. https://doi.org/10.1128/AEM.00270-07.

Martín-Hernández, R., Botías, C., Garrido Bailón, E., Martinez Salvador, A., Prieto, L., Meana, A., Higes, M. (2012). Microsporidia infecting Apis mellifera: coexistence or competition. Is Nosema ceranae replacing Nosema apis ?. Environ. Microbiol. 14 (8): 2127-2138. https://doi.org/10.1111/j.1462-2920.2011.02645.x.

Martín-Hernández, R., Bartolomé, C., Chejanovsky, N., Le Conte, Y., Dalmon, A., Dussaubat, C., García-Palencia, P., Meana, A., Pinto, M. A., Soroker, V., Higes, M. (2018). Nosema ceranae in Apis mellifera: a 12 years post detection perspective. Environ. Microbiol. 20 (4): 1302-1329. https://doi.org/10.1111/1462-2920.14103.

Meana, A., Llorens-Picher, M., Euba, A., Bernal, J., García-Chao, M., Dagnac, T., Castro-Hermida, J. A., González-Porto, A. V., Higes, M., Martín-Hernández, R. (2017). Risk factors associated with honeybee colony loss in apiaries in Galicia, NW Spain. Span. J. Agric. Res. 15 (1): 1-11. https://doi.org/10.5424 /sjar/2017151-9652.

Medici, S., Sarlo, E., Porrini, M., Braunstein, M., Eguaras, M. (2012). Genetic variation and widespread dispersal of Nosema ceranae in Apis mellifera apiaries from Argentina. Parasitol. Res. 110, 859-864. https://doi. org/10.1007/s00436-011-2566-2.

Meixner, M., Francis, R., Gajda, A., Kryger, P., Andonov, S., Uzunov, A., Topolska, G., Costa, C., Amiri, E., Berg, S., Bienkowska, M., Bouga, M., Büchler, R., Dyrba, W.,Gurgulova, K., Hatjina, F., Ivanova, E., 
Janes, M., Kezic, N., Korpela, S., Le Conte, I., Panasiuk, B., Pechhacker, H., Tsoktouridis, G., Vaccari, G., Wilde, J. (2014). Occurrence of parasites and pathogens in honeybee colonies used in a European genotype-environment interactions experiment. J. Apic. Res. 53 (2): 215-229. https://doi.org/10.3896 /IBRA.1.53.2.04.

Moeller, F. (1972). Effects of emerging bees and of winter flights of nosema disease in honeybee colonies. J. Apic. Res. 2 : 117-120. https://doi.org/10.1080 /00218839.1972.11099709

Moeller, F. (1978). Nosema disease - its control in honeybee colonies. U.S. Department of Agriculture Technical Bulletin No. 1569. Department of Agriculture, Science and Education Administration.

Moher, D., Hopewell, S., Schulz, K., Montori, V., Gotzsche, P., Devereaux, P. J., Elbourne, D., Egger, M., Altman, D. G. (2010). CONSORT 2010 explanation and elaboration: Updated guidelines for reporting parallel group randomized trials. BMJ 10(1): 28-55. https://doi.org/10.1016/j.ijsu.2011.10.001.

Molineri, A., Giacobino, A., Pacini, A., Bulacio Cagnolo, N., Merke, J., Orellano, E., Bertozzi, E., Masciángelo, G., Zago, L., Aignasse, A., Pietronave, H., Rodríguez, G., Crisanti, P., Palacio, M. A., Signorini, M. (2018). Environment and Varroa destructor management as determinant of colony losses in apiaries under temperate and subtropical climate, J. Apic. Res. https://doi. org/10.1080/00218839.2018.1475697.

Muñoz, I., Cepero, A., Pinto, M., Martín-Hernández, R., Higes, M., De la Rúa, P. (2014) Presence of Nosema ceranae associated with honeybee queen introductions. Infect. Genet. Evol. 23 : 161-168. https://doi. org/10.1016/j.meegid.2014.02.008.

Pacini, A., Mira, A., Molineri, A., Giacobino, A., Bulacio Cagnolo, N., Aignasse, A., Zago, L., Izaguirre, M., Merke, J., Orellano, E., Bertozzi, E., Pietronave, H., Russo, R., Scannapieco, A., Lanzavecchia, S., Schnittger, L., Signorini, M. (2016a). Distribution and prevalence of Nosema apis and N. ceranae in temperate and subtropical eco-regions of Argentina. J. Invertebr. Pathol. 141, 34-37. https://doi. org/10.1016/j.jip.2016.11.002.

Pacini, A., Giacobino, A., Molineri, A., Bulacio-Cagnolo, N., Aignasse, A., Zago L, Mira, A., Izaguirre, M., Schnittger, L., Merke, J., Orellano, E., Bertozzi, E., Pietronave, H., Signorini, M. (2016b). Risk factors associated with the abundance of Nosema spp. in apiaries located in temperate and subtropical conditions after honey harvest. J. Apic. Res. 55 (4): 342-350. https://doi.org/10.1080 /00218839.2016.1245396.

Pettis, J., van Engelsdorp, D., Johnson, J., Dively, G. (2012) Pesticide exposure in honeybees results in increased levels of the gut pathogen Nosema. Naturwissenschaften. 99: 153-158. https://doi. org/10.1007/s00114-011-0881-1.

Pfeiffer, D., Robinson, T., Stevenson, M., Stevens, K., Rogers, D., et al (2008). Spatial Analysis in Epidemiology, 1era edición. Oxford University Press, Gran Bretaña, pp. 142.
Potts, S., Biesmeijer, J., Kreme, C., Neumann, P., Oliver, S., Kunin, W. E. (2010). Global pollinator declines trends, impacts and drivers. Trends Ecol. Evol. 25 (6): 345-353. https://doi.org/10.1016/j. tree.2010.01.007.

Rangel, J., Baum, K., Rubink, W.L., Coulson, R. N., Johnston, J. S., Traver, B. E. (2016). Prevalence of Nosema species in a feral honeybee population: a 20 -year survey. Apidologie. 47 : 561-571. https://doi.org/10.1007 /s13592-015-0401-y.

Red de Información Agropecuaria Nacional [RIAN]. (2010). Zonificación RIAN Chaco y Formosa [RIAN zonification Chaco and Formosa]. EEA Saenz Peña, Chaco: Publicación INTA. Available in: https://inta. gob.ar/documentos/zonificacion-rian-de-chaco-formosa. Accessed 20 Oct 2017.

Requier, F., Andersson, G., Oddi, F., Garcia, N., Garibaldi, L. (2018). Perspectives from the Survey of Honey Bee Colony Losses During 2015-2016 in Argentina. Bee World, 95 :(1): 9-12. https://doi.org/10.1080/0005772 X.2018.1413620.

Retschnig, G., Williams, G., Schneeberger, A., Neumann, P. (2017). Cold Ambient Temperature Promotes Nosema spp. Intensity in Honey Bees (Apis mellifera). Insects. https://doi.org/10.3390/insects8010020.

Riveros, F. (2009). El gran Chaco [The biggest Chaco]. Retrieved from: http:// ww w fao. org/ag/agp/agpc/doc/counprof/spanishtrad/argentina sp/granchaco/GranChaco_sp.htm. Accessed $2 \overline{0}$ Oct 2017.

Sarlo, E. (2010). Aportes al conocimiento de la naturaleza y control de la Microsporidiosis causada por Nosema ceranae (Microsporidia, Nosematidae) en las colonias de Apis mellifera (Hymenoptera, Apidae) asentadas en la región sudeste de la provincia de Buenos Aires, Argentina. [Contributions to the knowledge of the nature and control of Microsporidiosis caused by Nosema ceranae (Microsporidia, Nosematidae) in colonies of Apis mellifera (Hymenoptera, Apidae) settled in the southeastern region of the province of Buenos Aires, Argentina] (Thesis Doctoral). Facultad de Ciencias Exactas y Naturales. Universidad Nacional de Mar del Plata, Mar del Plata, Argentina.

Schaaf, A.A. (2013). Pesticides use and toxicity: survey in the agricultural zone of San Vicente, Santa Fe, Argentina. Revista Mexicana de Ciencias Agricolas 4(2): 323-331. (Spanish).

Servicio Nacional de Sanidad y calidad Agroalimentaria (SENASA), (2013). Programa Nacional de Sanidad Apícola- RESOLUCION 278/2013. Available: h t t p :// w w w. s e n a s a gob.ar/caden a animal/abejas/produccion-primaria/sanidad-apicola. Accessed 12 Dec 2017.

Signorini, M., Molineri, A., Bulacio Cagnolo, N., Merke, J., Luiselli, S., Caporgno, J. (2014). Evaluación a campo de la efectividad del tratamiento contra Nosemosis en apiarios de la provincia de Santa Fe. [Field evaluation of effectiveness of Nosemosis treatment in apiaries from Santa Fe province]. Revista FAVE - Ciencias Veterinarias 9 (1): 7-16. https://doi. org/10.14409/favecv.v9i1.1491. 
Simeunovic, P., Stevanovic, J., Cirkovic, D., Radojicic, S., Lakic, N., Stanisic, L., Stanimirovic, Z. (2014). Nosema ceranae and queen age influence the reproduction and productivity of the honeybee colony. J. Apic. Res. 53: 545-554. https://doi.org/10.3896 /IBRA.1.53.5.09.

Simone-Finstrom, M., Li-Byarlay, H., Huang, M., Strand, M., Rueppell, O., Tarpy, D. (2016). Migratory management and environmental conditions affect lifespan and oxidative stress in honey bees. Sci. Rep. $6: 32023$. https://doi.org/10.1038/srep32023.

Soroker, V., Hetzroni, A., Yakobson, B., David, D., David, A., Voet, H., Slabezki, Y., Efrat, H., Levski, S., Kamer, Y., Klinberg, E., Zioni, N., Inbar, S., Chejanovsky, N. (2011). Evaluation of colony losses in Israel in relation to the incidence of pathogens and pests. Apidologie. 42, 192. https://doi.org/10.1051/apido/2010047.

Steinhauer, N., Rennich, K., Wilson, M., Caron, D., Lengerich, E., et al (2014). A national survey of managed honeybee 2012-2013 annual colony losses in the USA: Results from the Bee Informed Partnership. J. Apic. Res. 53 (1): 1-18. https://doi.org/10.3896 /IBRA.1.53.1.01.

Stevanovic, J., Stanimirovic, Z., Genersch, E. et al (n.d.-a). Dominance of Nosema ceranae in honey bees in the Balkan countries in the absence of symptoms of colony collapse disorder. Apidologie. 42, 49. https://doi. org/10.1051/apido/2010034.

Stevanovic, J., Simeunovic, P., Gajic, B. et al (n.d.-b). Characteristics of Nosema ceranae infection in Serbian honey bee colonies. Apidologie. 44, 522-536. https://doi.org/10.1007/s13592-013-0203-z.

Thrusfield, M., Christley, R., Brown, H., Diggle, P. J., French, N., et al. (2018). Veterinary Epidemiology. Fourth Edition. Chapter 24. Risk analysis. Wiley Online Library. 540-564. https://doi.org/10.1002 /9781118280249.ch24.

Traver, B.E., Fell, R.D. (2011). Prevalence and infection intensity of Nosema in honey bee (Apis mellifera L.) colonies in Virginia. J. Invertebr. Pathol. 107: 43-49. https://doi.org/10.1016/j.jip.2011.02.003.

Traver, B.E., Fell, R.D. (2012). Low natural levels of Nosema ceranae in Apis mellifera queens. J. Invertebr. Pathol. 110: 408-410. https://doi. org/10.1016/j.jip.2012.04.001.
Traver, B.E., Williams M.R., Fell, R.D. (2012). Comparison of within hive sampling and seasonal activity of Nosema ceranae in honey bee colonies. J. Invertebr. Pathol. 109: 187-193. https://doi.org/10.1016/j. jip.2011.11.001.

Urbieta-Magro, A., Higes, M., Meana, A., GómezMoracho, T., Rodríguez-García, C., Barrios, L., Martín-Hernández, R. (2019). The levels of natural Nosema spp. infection in Apis mellifera iberiensis brood stages. Int. J. Parasitol. 49: 657-667. https://doi.org/10.1016/j.ijpara.2019.04.002.

Van Der Zee, R., Brodschneider, R., Brusbardis, W., Charrière, J., Chlebo, R., Coffey, M. F., Dahle, B., Drazic, M., Kauko, L., Kretavicius, J., et al (2014). Results of international standardised beekeeper surveys of colony losses for winter 2012-2013: analysis of winter loss rates and mixed effects modelling of risk factors for winter loss. J. Apic. Res. 53 (1): 19-34. https://doi.org/10.3896/IBRA.1.53.1.02.

van Engelsdorp, D., Meixner, M. (2010). A historical review of managed honeybee populations in Europe and the United States and the factors that may affect them. J. Invertebr. Pathol. 103, Supplement:S80-S95. https://doi.org/10.1016/j.jip.2009.06.011.

van Engelsdorp, D., Evans, J., Saegerman, C., Mullin, C., Haubruge, E. (2009). Colony collapse disorder: A descriptive study. PLoS One. 4, e6481. https://doi. org/10.1371/journal.pone.0006481.

Vidau, C., Diogon, M., Aufauvre, J., Fontbonne, R., Viguès, B., Brunet, J.L., Texier, C., Biron, D.G., Blot, N., El Alaoui, H., Belzunces, L.P., Delbac, F., (2011). Exposure to sublethal doses of fipronil and thiacloprid highly increases mortality of honeybees previously infected by Nosema ceranae. PLoS One. 6 : e21550. https://doi.org/10.1371/journal.pone.0021550.

Williams, G., Head, K., Burgher-MacLellan, K., Rogers, R., Shutler, D. (2010). Parasitic mites and microsporidians in managed western honeybee colonies on the island of Newfoundland, Canada. Can. Entomol. 142 (6): 584-588. https://doi.org/10.4039 /n10-029.

Publisher's note Springer Nature remains neutral with regard to jurisdictional claims in published maps and institutional affiliations. 